\title{
ENTRE LEITURA, LITERATURA INFANTO-JUVENIL E LINGUAGENS: UMA CONVERSA COM ANA MARIA MACHADO
}

\author{
Ana Maria Machado \\ Premiada escritora da literatura infantil e juvenil brasileira \\ Imortal da Academia Brasileira de Letras
}

Entrevistada por: Everaldo Lima de Araújo Doutorando em Letras - Língua Portuguesa - pela Universidade do Estado do Rio de Janeiro (UERJ) ever.lima.araujo@gmail.com

Márcia da Gama Silva Felipe Doutoranda em Letras - Língua Portuguesa - pela Universidade do Estado do Rio de Janeiro (UERJ) prof.marciadagama@gmail.com

Thales Sant'Ana Ferreira Mendes Mestrando em Letras - Literatura Brasileira - pela Universidade do Estado do Rio de Janeiro (UERJ) thales.sanfer@hotmail.com

Ana Maria Machado nasceu em Santa Teresa, no Rio de Janeiro. Formada em Letras pela Universidade do Brasil (atual Universidade Federal do Rio de Janeiro), onde também realizou estudos de pós-graduação, é a sexta ocupante da cadeira no 1 da Academia Brasileira de Letras ( $A B L$ ), para a qual ingressou em agosto de 2003. Foi presidente da instituição durante os anos de 2012 e 2013. Ana Maria Machado já foi professora da UFRJ e da PUC-Rio, além de ter trabalhado no Correio da Manhã, no Jornal do Brasil, n'O Globo e colaborado com as revistas Realidade, Isto É e Veja. Seu maior reconhecimento, no entanto, se deve à sua extensa e sólida obra de literatura infantojuvenil, tendo escrito livros como Raul da ferrugem azul (1979), Palavras, palavrinhas, palavrões (1981), O menino que espiava pra dentro (1984), Menina bonita do laço de fita (1986) e Tudo ao mesmo tempo agora (1997). É também autora de romances, como Alice e Ulisses (1983) e Tropical sol da liberdade (1988), além de ensaios do porte de Recado do nome (1976) e Romântico, sedutor e anarquista: como e por que ler Jorge Amado hoje (2006). Recebeu, dentre vários outros prêmios nacionais, três Jabuti, o Machado de Assis ( $A B L, 2001$ ), pelo conjunto da obra, e, no exterior, prêmios como o Hans Christian Andersen (Suíça, 2000), pelo conjunto da obra infantil, e o Príncipe Claus (Holanda, 2010). É, ainda, membro do PEN Clube do Brasil e do Seminário de Literatura da Universidade de Cambridge, na Inglaterra. 


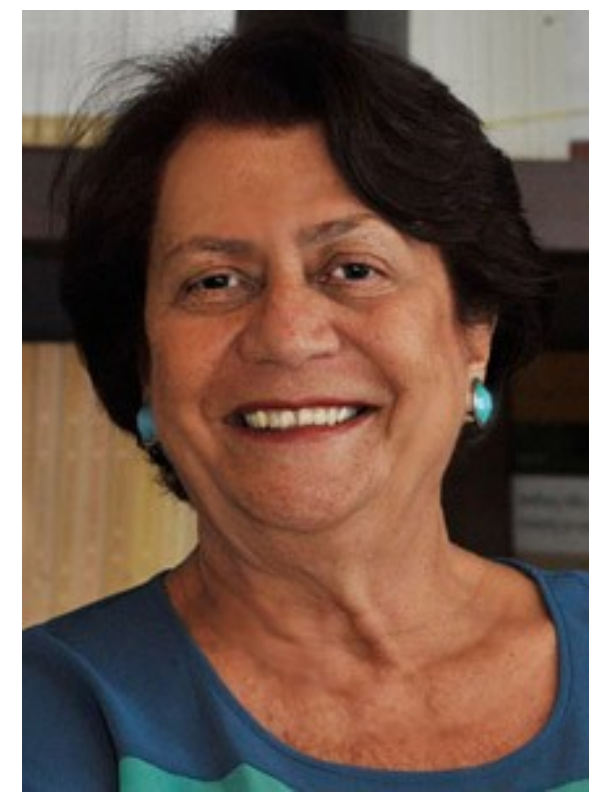

\section{PALIMPSESTO}

1) Qual a sua opinião acerca de um equívoco muito frequente no mercado em relação à "confusão" entre literatura infantil e livros para crianças?

\section{ANA MARIA MACHADO}

No sintagma literatura infanto-juvenil, o que importa é o substantivo LITERATURA, não o adjetivo INFANTO-JUVENIL. A substância, não uma qualidade adjunta. Ainda mais porque, no caso, ocorre um fenômeno raro, como vários analistas já assinalaram fartamente, no Brasil e no exterior. Não se trata de um adjetivo que restringe o sentido do substantivo, mas que o amplia. Trata-se de uma literatura também ao alcance de leitores infantis, não apenas a seu alcance. Se não tiver qualidades para o leitor nãoinfantil, não será literatura. Essa é a diferença para a literatura não-infantil, que está apenas ao alcance de leitores não infantis, mas não consegue falar à criança. 


\section{PALIMPSESTO}

2) Por um tempo, a literatura infanto-juvenil foi vista como um gênero menor dentro da produção literária. Essa visão ainda permanece nos dias de hoje?

\section{ANA MARIA MACHADO}

Imagino que sim, nos setores que não a conhecem e ainda se pautam por visões antiquadas e preconceituosas. Mas quem conhece o assunto tem grande respeito por ela.

\section{PALIMPSESTO}

3) Qual a relação entre literatura infantil e diversão?

\section{ANA MARIA MACHADO}

É uma relação que existe, como em toda literatura. Mas tem doses diferentes nas diferentes obras. Na literatura adulta, por exemplo, alguns autores (como Graham Greene) sempre fizeram questão de distinguir entre suas obras mais sérias e os "divertissements" que escreveram. Outros deixaram a distinção por conta do leitor. Já desde os clássicos greco-romanos, como Horácio, se reconhecia na literatura um duplo papel, utile et dolce, ou seja, o de ser útil e dar prazer. O que foi mudando, talvez, foi o que se reconhecia como utilidade - que tanto significou explorar as profundezas do espírito humano como analisar as forças sociais que agem em um contexto histórico. E a noção de diversão, geralmente mais associada a aspectos formais e busca de beleza na expressão, por vezes se confundiu com a de entretenimento, de passar o tempo de modo 
agradável e leve. A literatura infantil não foge disso. Mas como toda literatura, se for apenas superficial e divertida, não se sustenta de modo duradouro. Tem que apresentar um desafio intelectual, criar ambiguidades, estimular interpretações diversas e reapropriações múltiplas. Isso vale para a literatura infantil e a adulta ou senil, conforme o adjetivo que se prefira.

\section{PALIMPSESTO}

4) Muitas escolas adotam livros paradidáticos cuja leitura é obrigatória. Como lidar, nesse caso, com o incentivo à leitura, tendo em vista as avaliações demandadas pelas mesmas escolas?

\section{ANA MARIA MACHADO}

Em função do meu distanciamento da sala de aula, não faço ideia. É uma pergunta que deve ser dirigida a pedagogos ou outros que estejam mais diretamente ligados aos alunos.

\section{PALIMPSESTO}

5) Os livros de literatura infanto-juvenil, de modo geral, têm algum compromisso com a formação de seus leitores?

\section{ANA MARIA MACHADO}


Não posso falar em termos gerais. Acredito que todos os livros de literatura - e não apenas os infanto-juvenis -- desempenham um papel na formação de seus leitores, ao expô-los a ideias, emoções e reflexões variadas que ultrapassam o indivíduo leitor, dando-Ihe a oportunidade de vivenciar experiências diferentes das suas, ainda que ficcionalmente ou em termos puramente emocionais. Mas não acho que se trate de um compromisso e sim de um reflexo do contato com o pensamento alheio, exposto de forma estética. É uma forma poderosa de contato com a alteridade, indo muito além do círculo de convívio imediato, o que me parece fundamental para a formação do ser humano.

\section{PALIMPSESTO}

6) Os livros da senhora frequentemente tratam de temas atuais e - por assim dizer polêmicos. Como a senhora enxerga o poder da literatura infanto-juvenil no trato de tais temas?

\section{ANA MARIA MACHADO}

A resposta a essa pergunta está muito ligada à anterior. Acho que é inevitável que o que eu escrevo reflita o que penso e sinto sobre a época em que vivo e o país e a sociedade que me cercam. Mas, muitas vezes, o enredo conta uma ação que se passa em locais imaginários ou épocas remotas. Acho que isso faz parte do poder de toda e qualquer literatura: o de falar do que bem entende, nos termos que desejar. Não acho que, no caso da literatura, tratar de qualquer tema esteja vinculado a uma intenção. Posso garantir que, no meu caso, não é assim que funciona. Minha intenção é expressar 
perplexidades, dúvidas, perguntas, buscas, encantamento com certos mistérios e com a própria linguagem. Preferencialmente, de modo algo ambíguo, que dê espaço para o leitor procurar seus próprios caminhos e formular suas hipóteses, sem lhe fornecer respostas prontas. Não quero dar lição a ninguém, mas propor exploração de enigmas. Dar espaço a diversos níveis de leitura, capaz de ser fecunda em sua polissemia e multivocidade.

\section{PALIMPSESTO}

7) Que mensagem a senhora deixa para aqueles que pretendem despertar em seus alunos o hábito da leitura?

\section{ANA MARIA MACHADO}

Quando comecei a escrever e me faziam essa pergunta, eu costumava brincar e dizer que quem se importa com a transmissão de mensagens é telegrafista. Hoje diria que é a internet.

O fato de eu encontrar essa pergunta repetida, há meio século, me comprova que ainda há muito preconceito em relação à literatura infanto-juvenil. Ninguém ousaria fazer essa pergunta a Drummond ou Clarice, a Raduan Nassar ou Lygia Fagundes Telles. Claramente se entende que se trata de uma questão para o professor que pretende estimular a leitura do aluno, não para o autor que está às voltas com o embate com a linguagem em sua escrita. 


\section{READING, CHILDREN'S LITERATURE AND LANGUAGE: A CONVERSATION WITH ANA MARIA MACHADO}

Translated by:

Thales Sant'Ana Ferreira Mendes MA student in Brazilian Literature (Universidade do Estado do Rio de Janeiro, UERJ) thales.sanfer@hotmail.com

Ana Maria Machado was born in Rio de Janeiro. Graduated with a bachelor's degree in Letters at Universidade Federal do Rio de Janeiro (UFRJ), she has been member of the Academia Brasileira de Letras (Brazilian Academy of Letters) since 2003. She was president of the institution in 2012 and 2013. Ana Maria Machado has already been Professor at UFRJ and PUC-Rio, and has worked for newspapers as Correio da Manhã, Jornal do Brasil and O Globo and for magazines as Realidade, Isto É, Veja and Elle (Paris). She is most recognized due to her solid and extensive work for children, that includes books as Raul da ferrugem azul (1979), Palavras, palavrinhas, palavrões (1981), O menino que espiava pra dentro (1984), Menina bonita do laço de fita (1986) and Tudo ao mesmo tempo agora (1997). She also has written books for adults, as Alice e Ulisses (1983) e Tropical sol da liberdade (1988), besides essays as Recado do nome (1976) and Romântico, sedutor e anarquista: como e por que ler Jorge Amado hoje (2006). She has received, among other Brazilian awards, three Jabuti Prize and the Machado de Assis Prize (ABL, 2001); in other countries, she was awarded the prestigious Hans Christian Andersen (Switzerland, 2000), for her contributions to the world of children's literature, and the Prince Claus Awards (Netherlands, 2010). She is a member of Brazil's PEN Club. 


\section{PALIMPSESTO}

1) What is your opinion about a very frequent misconception in the market regarding the "confusion" between children's literature and children's books?

\section{ANA MARIA MACHADO}

In the noun phrase children's literature, what matters is the noun literature, and not the adjective children. Especially because, in this case, a rare phenomenon occurs, as several analysts have already pointed out, in Brazil and abroad. It is not an adjective that restricts the meaning of the noun, but an adjective that extends it. It is a literature that is also for children and not only for children. If it does not have qualities for the non-child reader, it will not be literature. This is a difference to non-children's literature, which is only for non-child readers, which cannot speak to them.

\section{PALIMPSESTO}

2) There was a time children's literature was considered a smaller genre within the literary world. Do you think that this point of view still holds on nowadays?

\section{ANA MARIA MACHADO}

I suppose so, especially in those sectors that do not know it properly and still are guided by old-fashioned and prejudiced points of view. However, those ones who know the subject have great respect for it. 


\section{PALIMPSESTO}

\section{3) What is the relation between children's literature and amusement?}

\section{ANA MARIA MACHADO}

It is a relation that exists, as it occurs in all kind of literature. However, it has different rates in different works. In adult literature, for example, some authors (as Graham Greene, for example) have always made a point of distinguishing between their more serious works and the divertissements they wrote. Other ones have left the distinction on the reader's account. Among the Greek and Roman classics, like Horatio, literature was taken as having a double role, utile et dolce, i.e., to be useful and to give pleasure. What has been changing, perhaps, is what has been considered as useful - as much as it meant exploring the depths of the human spirit as well as analyzing the social forces that act in a historical context. The notion of fun, usually more associated to form and pursuit of beauty in expression, has been confused, for many times, with entertainment, as a kind of passing the time in a pleasant way. Children's literature is not an exception. However, like all literature, if it is only superficial and amusing, it does not sustain itself in a lasting way. It should be an intellectual challenge, it must create ambiguities, stimulate various interpretations, multiple appropriations. This is true for children's, adult's or elderly's literature, whatever adjective one prefers.

\section{PALIMPSESTO}


4) Many schools adopt some literary textbooks whose reading is mandatory. How to deal, in this case, with reading incentive, considering the exams required by these schools?

\section{ANA MARIA MACHADO}

Because of my distance from the classroom, I have no idea. This is a question that should be addressed to pedagogues or others ones more directly connected with students.

\section{PALIMPSESTO}

5) Do children's books use to have any commitment to the intellectual development of their readers?

\section{ANA MARIA MACHADO}

I cannot answer in a general sense. I believe that all literature books - not just children's books - play a role in the formation of their readers by exposing them to varied ideas, emotions, and reflections that go beyond the individual reader, giving them the opportunity to have experiences that differ from those ones that they have, albeit fictionally or in purely emotional terms. However, I do not think it is a kind of commitment, but a reflection of the contact with the thought of others, exposed in an aesthetic way. It is a powerful form of contact with otherness, going far beyond the circle 
Ana Maria Machado, Everaldo L. de Araújo, Márcia da Gama S. Felipe e Thales Sant'Ana F. Mendes

of immediate social life, which seems to me something fundamental for the formation of the human being.

\section{PALIMPSESTO}

6) Your books often deal with current and controversial themes. How do you see the power of children's literature in dealing with such topics?

\section{ANA MARIA MACHADO}

The answer for this question is linked to the previous one. I think it is inevitable that what I write reflects what I think and feel about the time in which I live and about the country and the society around me. Nevertheless, very often, the plot tells an action that takes place in imaginary places or remote times. I think that this is part of the power of any literature: to speak what you want, using the terms you wish. I do not think that, in the case of literature, dealing with any subject is linked to an intention. I can guarantee that, in my case, this is not how it works. My intention is to express perplexities, doubts, questions, searches, enchantment with certain mysteries and with the language itself. Preferably, in a rather ambiguous way, so that it gives space for the reader to seek his own ways and formulate his own hypotheses, without giving him ready answers. I want to propose explorations of puzzles, to give space to different levels of reading, capable of being fruitful in its polysemy.

\section{PALIMPSESTO}


7) What message do you leave to those ones who try to arouse in their students the habit of reading?

\section{ANA MARIA MACHADO}

When I began writing and they asked me that question, I used to jest and say that who cares about the transmission of messages is a telegraph operator. Today I would say it is the internet.

The fact that I have seen this question being repeated for half a century proves that there is still a lot of prejudice in relation to children's literature. No one would dare ask this question to Carlos Drummond de Andrade or Clarice Lispector, Raduan Nassar or Lygia Fagundes Telles. It is clearly understood that this is a question for the teacher who wants to stimulate the reading of the student, not for the author who is dealing with the clash with the language in his writing. 